\title{
EFEKTIVITAS MODEL PBL(PROBLEM BASED LEARNING) MENGGUNAKAN MEDIA LAGU RUMUS MATEMATIKA TERHADAP HASIL BELAJAR SISWA KELAS V SEKOLAH DASAR
}

\author{
Wulan Sutriyani ${ }^{1}$, Herwin Widyatmoko ${ }^{2}$ \\ Program Studi Pendidikan Guru Sekolah Dasar \\ Universitas Islam Nahdlatul Ulama Jepara \\ sutriyani.wulan@gmail.com¹, herwinwidyatmoko07@gmail.com²
}

\begin{abstract}
ABSTRAK
Tujuan penelitian ini yaitu untuk menguji keefektifan model pembelajaran Problem Based Learning menggunakan media lagu rumus matematika dalam meningkatkan hasil belajar siswa kelas $\mathrm{V}$ Sekolah Dasar dan untuk menguji perbedaan antara efektifitas penggunaan model pembelajaran Problem Based Learning media lagu rumus matematika pada kelompok eksperimen dan kelompok kontrol. Penelitian ini termasuk jenis penelitian eksperimen semu (quasi experiment research).Sempel penelitian ada 30 siswa yaitu, 15 siswa sebagai kelompok eksperimen dan 15 siswa sebagai kelompok kontrol.Dari uji $t$ yang telah dilakukan pada hasil belajar matematika, dapat diketahui bahwa hasil kelas eksperimen lebih tinggi daripada kelas kontrol. T hitung 3,469> T tabel 2,145 dapat disimpulkan bahwa Ho ditolak dan Ha diterima. Hal ini berarti ada perbedaan rata-rata hasil belajar antara kelompok eksperimen dan kelompok kontrol. Sehingga, ada perbedaan efektivitas yang signifikan antara penggunaan model pembelajaran PBL menggunakan media lagu rumus matematika dengan model pembelajaran konvensional untuk meningkatkan hasil belajar dalam mata pelajaran Matematika pada Siswa Kelas V SD N 1 Tegalsambi Tahun Pelajaran 2019/2020.
\end{abstract}

Kata Kunci:PBL, Media Lagu Rumus Matematika, Hasil Belajar.

\section{Pendahuluan}

Pendidikan merupakan salah satu aspek yang menjadi penentu kecerdasan suatu bangsa. Untuk itu diperlukan lembaga pendidikan dan guru dalam melakukan pembelajaran yang kreatif dan inovatif. Pembelajaran kreatif dan inofatif belum sepenuhnya diterapkan oleh lembaga pendidikan khususnya di Jepara. Hal ini terlihat dengan masih rendahnya hasil belajar siswa sekolah dasar maupun kualitas model pembelajaran yang dilakukan oleh guru. (Muntoha, 2015)

Padahal seharusnya pendidikan di Jepara mempunyai nilai lebih dan berkualitas, karena Jepara merupakan daerah kelahiran tokoh emansipasi wanita yang memperjuangkan hak-hak perempuan dalam memperoleh pendidikan yaitu R.A.Kartini. Sehingga harapannya dari generasi yang dihasilkan oleh pendidikan Jepara adalah generasi cerdas, terampil dan berkarakter bukan malah sebaliknya.

Berdasarkan hasil observasi dan wawancara dengan guru SDN 02 Tegalsambi kelas $\mathrm{V}$ pada tanggal 19 November 2019 dan SDN 01 Tegalsambi 


\section{Wulan Sutriyani dan Herwin Widyatmoko : Efektivitas Model Pbl(Problem Based Learning) Menggunakan Media Lagu Rumus Matematika Terhadap Hasil Belajar Siswa Kelas V \\ Sekolah Dasar}

kelas V pada tanggal 21 November 2019 yang menyatakan bahwa dalam implementasi kurikulum 2013 terdapat beberapa permasalahan yaitu pembelajaran di kelas masih bersifat teacher centered learning atau pembelajaran masih berpusat pada guru, (2) guru tidak cukup waktu untuk mempersiapkan pembelajaran dengan menyajikan masalah ataupun membentuk kelompok kooperatif karena harus mengejar materi ujian, (3) siswa tidak memiliki minat dan semangat untuk mempelajari materi secara mendalam, karena siswa di sini diposisikan sebagai obyek pembelajaran.

Menindak lanjuti hasil observasi dan wawancara, maka peneliti berupaya melakukan penelitian dengan menerapkan pembelajaran kreatif dan inovatif dengan melibatkan siswa aktif belajar dan terlibat secara langsung. Salah satu yang dapat dilakukan guru dengan menerapkan pembelajaran kreatif dan inovatif adalah dengan menggunakan model pembelajaran Problem Based Learning. Menurut Masholekhatin (2013) model pembelajaran Problem Based Learning memberikan kebebasan kepada siswa untuk belajar sesuai dengan minat dan perhatiannya sehingga dalam Problem Based Learning siswa akan terlibat intensif dan aktif, yang pada akhirnya bisa membuat siswa untuk terus belajar dan dapat meningkatkan hasil belajar.

Sejalan dengan hasil penelitian Astari, dkk (2018) yang menyatakan bahwa efektifitas pengguna model problem based learning berpengaruh terhadap hasil belajar, karena melalui pembelajaran ini peserta didik belajar bagaimana menggunakan konsep dan proses interaksi untuk menilai apa yang mereka ketahui, mengidentifikasi apa yang ingin diketahui, mengumpulkan informasi dan secara kolaborasi mengevaluasi hipotesisnya berdasarkan data yang dikumpulkan.

Keberhasilan pendekatan PBL tergantung pada dua faktor, yaitu (1) jenis masalah yang dikonfrontasikan kepada siswa yaitu masalah yang menuntut pemecahan berdasarkan PBL dan (2) formasi dan kebermanfaatan fungsi kelompok kooperatif untuk memaksimalkan aktivitas dan partisipasi siswa secara keseluruhan (Heller, 2010). Sehingga pada penelitian ini masalah yang diangkat dalam pembelajaran Problem Based Learning diangkat dari produk-produk yang dihasilkan Jepara yaitu batik Troso, mebel, ukiran, gerabah, maupun batik Jepara. 


\section{Wulan Sutriyani dan Herwin Widyatmoko : Efektivitas Model Pbl(Problem Based Learning) Menggunakan Media Lagu Rumus Matematika Terhadap Hasil Belajar Siswa Kelas V \\ Sekolah Dasar}

Untuk memaksimalkan penerapan model PBL dalam pembelajaran tersebut maka juga diperlukan penggunaan suatu media yaitu berupa media lagu. Media lagu yang dipakai merupakan media lagu yang berisi rumus matematika. Aizid (2011:17) menyatakan bahwa lagu atau musik dapat meningkatkan intelegensi karena rangsangan ritmis mampu meningkatkan fungsi kerja otak manusia, seperti membuat saraf-saraf otak bekerja serta menciptakan rasa nyaman dan tenangsehingga fungsi kerja otak menjadi optimal. Rangsangan ritmis dari lagu yang diperdengarkan itulah yang dapat meningkatkan kemampuan berbahasa, kreativitas, konsentrasi, dan daya ingat.

Berdasarkan seluruh uraian diatas, serta diperkuat dengan hasil penelitian Wulandari, dkk (2018) menyebutkan bahwa pembelajaran menggunakan Problem Based Learning dapat meningkatkan hasil belajar siswa kelas V SD dalam muatan pelajaran IPA. Maka peneliti perlu melakukan penelitian dengan menerapkan pembelajaran berbasis masalah sebagai solusi alternatif memecahkan masalah yang sudah dipaparkan dengan judul "Efektivitas Model Problem Based Learning Menggunakan Media Lagu Rumus Matematika Terhadap Hasil Belajar Siswa Kelas V Sekolah Dasar".

\section{Metode Penelitian}

Penelitian dilaksanakan pada Semester 1 tahun pelajaran 2019/2020. Penelitian berlangsung pada bulan November 2019. Penelitian dilaksanakan di Kelas V SDN 01 \& 02 Tegalsambi, Kecamatan Tahunan, Kabupaten Jepara. Subjek penelitian adalah siswa Kelas V SDN 01 \& 02 Tegalsambi, Kecamatan Tahunan, Kabupaten Jeparatahun pelajaran 2019/2020 sebanyak 30 siswa. Pada penelitian ini, data dikumpulkan dengan melalui dokumentasi, observasi, jurnal, wawancara, dan tes.

Penelitian ini termasuk jenis penelitian eksperimen semu (quasi experiment research).Eksperimen semu merupakan jenis penelitian untuk memperoleh informasi yang diperoleh dengan eksperimen dalam keadaan yang tidak memungkinkan untuk mengontrol semua variabel-variabel luar yang mempengaruhi pelaksanaan eksperimen, Sugiyono (2013:77).

Dalam hal ini peneliti menggunakan subjek yang terdapat pada kelas 


\section{Wulan Sutriyani dan Herwin Widyatmoko : Efektivitas Model Pbl(Problem Based Learning) Menggunakan Media Lagu Rumus Matematika Terhadap Hasil Belajar Siswa Kelas V \\ Sekolah Dasar}

tersebut dan tidak mengacak subyek yang ada serta tidak membentuk kelas baru. Penelitian quasi experiment ini dilakukan dengan pemberian perlakuan (treatment) kepada suatu kelas yang selanjutnya disebut dengan kelas eksperimen akan diperbandingkan dengan kelas kontrol. Subjek penelitian ini adalah siswa kelas $\mathrm{V}$ SDN 1 Tegalsambi sebagai kelas eksperimen dan kelas V SDN 2 Tegalsambi Tahunan Jepara sebagai kelas kontrol.Teknik analisis data yang digunakan dalam penelitian ini adalah mengunakan analisis deskriptif, statistik deskriptif dan uji hipotesis menggunakan aplikasi SPSS 23.Sebelum melakukan uji hipotesis terlebih dahulu menguji kenormalan data dengan rumus KolmogorovSminov.Setelah diketahui data berdistribusi normal maka uji hipotesisnya menggunakan uji independent $t$ test. Prosedur dalam penelitian ini terdiri dari tiga tahap yaitu: 1) Tahap persiapan, 2) Tahap Pelaksanaan, 3) Tahap akhir.

Tahap Persiapan

Langkah-langkah yang dilakukan pada tahap persiapan antara lain: (1) Menentukan kelas untuk melakukan penelitian; (2) Peneliti berkoordinasi dengan guru kelas V untuk menentukan jadwal penelitian; (3) Membuat perangkat belajar berupa rencana pelaksanaan pembelajaran (RPP); (4) Melakukan validasi instrumen penelitian dan perangkat pembelajaran; (5) Merevisi instrumen penelitian dan perangkat pem belajaran berdasarkan hasil validasi; (6) Membuat media pembelajaran audio-visual yang digunakan untuk penelitian.

Tahap Pelaksanaan

Langkah-langkah yang dilakukan dalam tahap pelaksanaan antara lain: (1) Melakukan pretest kepada kelompok eksperimen maupun kelompok kontrol untuk mengetahui hasil belajar siswa sebelum diberikan perlakuan menggunakan media lagu rumus matematika; (2) Melakukan penelitian eksperimen dengan memberikan pembelajaran menggunakan media lagu rumus matematika pada kelompok eksperimen. Sedangkan kelompok kontrol tanpa diberi perlakuan; (3) Melakukan post test pada kelompok eksperimen maupun kelompok kontrol. Tahap Akhir

Langkah-langkah yang dilakukan pada tahap akhir antara lain: (1) Melakukan analisis dan pengolahan data hasil penelitian pra eksperimen dan eksperimen; (2) Menarik kesimpulan hasil penelitian; (3) Menyusun laporan penelitian. 
Wulan Sutriyani dan Herwin Widyatmoko : Efektivitas Model Pbl(Problem Based Learning)

Menggunakan Media Lagu Rumus Matematika Terhadap Hasil Belajar Siswa Kelas V

Sekolah Dasar

\section{Hasil Penelitian dan Pembahasan}

Penelitian dilaksanakan di SDN 01 dan 02 Tegalsambi Kecamatan Tahunan Kabupaten Jepara pada pada kelas V. Muatan yang digunakan dalam penelitian ini adalah matematika dengan materi volume bangun ruang.Berikut hasil dan pembahasan dari penelitian.

\section{Analisis Deskriptif}

Analisis deskriptif pretest nilai hasil belajar Matematika kelas eksperimen dan kelas kontrol yang terdiri dari nilai terendah, nilai tertinggi, nilai rata-rata, dan standard deviasi.

Tabel 1. Analisis Deskriptif Pretest Hasil Belajar Kelas Eksperimen dan Kelas Kontrol

\begin{tabular}{ccccc}
\hline & N & Min & Max & Mean \\
\hline Pre-test Eksperimen & 15 & 50 & 80 & 65,3 \\
Pre-test Kontrol & 15 & 45 & 75 & 66 \\
\hline
\end{tabular}

Berdasarkan table 3 , diperoleh data Pretest hasil belajar siswa yang menunjukan jumlah responden $(\mathrm{N})$ pada kelompok eksperimen sebanyak 15 dan mempunyai skor minimum 50 dan maksimal 80. Skor rata-rata kelompok eksperimen adalah 65,3, sedangkan pada kelompok pada kelompok kontrol mempunyai jumlah responden sebanyak 15 siswa. Skor minimum 45 dan skor maksimum 75 dengan rata-rata 66.hasilpengolahan di atas dapat memperjelas gambaran pretest hasil belajar matematika pada kelompok eksperimen dan kelompok kontrol.

Selanjutnya analisis deskriptif posttest nilai hasil belajar matematika kelas eksperimen dan kelas kontrol yang terdiri dari nilai terendah, nilai tertinggi, nilai rata-rata, dan standard deviasi.

Tabel 2. Analisis Deskriptif Posttest Hasil Belajar Kelas Eksperimen dan Kelas Kontrol

\begin{tabular}{ccccc}
\hline & N & Min & Max & Mean \\
\hline $\begin{array}{c}\text { Post-test } \\
\text { Eksperimen }\end{array}$ & 15 & 70 & 90 & 80,3 \\
\hline Post-test Kontrol & 15 & 60 & 80 & 72,3 \\
\hline
\end{tabular}

Berdasarkan table 4, diperoleh data Posttest hasil belajar siswa yang 


\section{Wulan Sutriyani dan Herwin Widyatmoko : Efektivitas Model Pbl(Problem Based Learning) Menggunakan Media Lagu Rumus Matematika Terhadap Hasil Belajar Siswa Kelas V \\ Sekolah Dasar}

menunjukan jumlah responden $(\mathrm{N})$ pada kelompok eksperimen sebanyak 15 dan mempunyai skor minimum 70 dan maksimum 90. Skor rata-rata kelompok eksperimen adalah 80,3, sedangkan pada kelompok pada kelompok kontrol mempunyai jumlah responden sebanyak 15 siswa. Skor minimum 60 dan skor maksimum 80 dengan rata-rata 72,3. hasil pengolahan di atas dapat memperjelas gambaran posttest hasil belajar matematika pada kelompok eksperimen dan kelompok kontrol.

Berdasarkan nilai NGain Score menunjukkan model PBL kurang efektif untuk meningkatkan hasil belajar dalam mata pelajaran matematika materibangun ruang pada siswa kelas $\mathrm{V}$, Sementara metode konvensional tidak efektif untuk meningkatkan hasil belajar.

2. Hasil Uji Perbedaan Rata-Rata atau Uji T Hasil Belajar Matematika

Tabel 3.Tests of Normality

\begin{tabular}{llllllll}
\hline & & \multicolumn{3}{c}{ Kolmogorov-Smirnov $^{\mathbf{a}}$} & \multicolumn{3}{c}{ Shapiro-Wilk } \\
\cline { 2 - 8 } & Kelompok & Statistic & df & Sig. & Statistic & df & \multicolumn{1}{l}{ Sig. } \\
\hline \multirow{2}{*}{$\begin{array}{l}\text { NGain } \\
\text { Persen }\end{array}$} & Eksperimen & .133 & 15 & $.200^{*}$ & .950 & 15 & .530 \\
\cline { 2 - 8 } & Kontrol & .163 & 15 & $.200^{*}$ & .911 & 15 & .142 \\
\hline
\end{tabular}

Berdasarkan tabel output Test of Normality di atas, diketahui nilai signifikansi dalam uji Shapiro wilk untuk Nilai Ngain Persen pada kelas eksperimen adalah 0,530 dan kelas control 0,142 . Karena nilai signifikansi kedua kelas tersebut lebih besar dari 0,05 maka dapat dikatakan bahwa data yang digunakan dalam penelitian ini berdistribusi normal.

Berdasarkan uji $t$ diperoleh, $T$ hitung 3,469> $T$ tabel 2,145 dapat disimpulkan bahwa Ho ditolak dan Ha diterima, yang berarti ada perbedaan ratarata hasil belajar antara kelompok eksperimen dan kelompok kontrol, dengan kata lain ada perbedaan efektivitas yang signifikan (nyata) antara penggunaan model pembelajaran PBL dengan model konvensional untuk meningkatkan hasil belajar dalam mata pelajaran matematika materi volume bangun ruang Pada Siswa Kelas V SD 1 Tegalsambi Tahun Pelajaran 2019/2020.

Dalam penelitian ini, mencari apakah terdapat perbedaaan efektivitas antara penggunaan model pembelajaran PBL dengan model konvensional learning untuk meningkatkan hasil belajar dalam mata pelajaran matematika 


\section{Wulan Sutriyani dan Herwin Widyatmoko : Efektivitas Model Pbl(Problem Based Learning) Menggunakan Media Lagu Rumus Matematika Terhadap Hasil Belajar Siswa Kelas V \\ Sekolah Dasar}

materi volume bangun ruang pada Siswa Kelas V SD 1 Tegalsambi sebagai kelas eksperimen dan SDN 2 Tegalsambi sebagai kelas kontrol Tahun Pelajaran 2019/2020.

Dari uji $t$ yang telah dilakukan pada hasil belajar matematika, dapat diketahui bahwa hasil kelas eksperimen lebih tinggi daripada kelas kontrol. T hitung 3,469> T tabel 2,145 dapat disimpulkan bahwa Ho ditolak dan Ha diterima, yang berarti ada perbedaan rata-rata hasil belajar antara kelompok eksperimen dan kelompok kontrol, dengan kata lain ada perbedaan efektivitas yang signifikan (nyata) antara penggunaan model pembelajaran PBL dengan model konvensional untuk meningkatkan hasil belajar dalam mata pelajaran Matematika materi volume bangun ruang pada Siswa Kelas V SDN 1 Tegalsambi Tahun Pelajaran 2019/2020.

Pelaksanaan pembelajaran $P B L$ menggunakan media lagu rumus matematika pada sub pokok bahasan materi volume bangun ruang ditunjang dengan rencana pelaksanaan pembelajaran yang sesuai. Melalui model pembelajaran tersebut siswa menjadi lebih aktif karena banyak aktifitas yang dilakukan dalam pembelajaran dan praktik menyanyikan lagu di kelas. Berdasarkan penelitian Afifah (2019) untuk meningkatkan kemampuan berpikir kritis matematis siswa lebih efektif jika menggunakan model Problem Based Learning.

Dalam penelitian proses kegiatan belajar, siswa dibagi menjadi 5 kelompok yang telah ditentukan sebelumnya. Kelompok-kelompok tersebut dihadapkan pada suatu permasalahan tentang soal volume bangun ruang. Siswa disuruh melakukan diskusi dengan teman kelompoknya yang sudah dibagi, dan melakukannya sesuai dengan petunjuk yang ada pada Lembar Kerja Siswa. Siswa kemudian belajar secara kolaboratif dan mengkonstruksi pengetahuan sendiri, pengalaman pada kehidupan sehari-hari. Melalui kegiatan diskusi, siswa belajar dan bekerja dengan kelompoknya masing-masing untuk menyelesaikan masalah tentang volume bangun ruang. Pada saat diberikan masalah siswa dituntut untuk memahami, bernalar dan kreatif dalam pemecahan masalah, Pada saat berdiskusi dan presentasi, siswa dituntut untuk berkomunikasi, mengemukakan ide kreatifnya dengan teman maupun guru. Pada akhir 


\section{Wulan Sutriyani dan Herwin Widyatmoko : Efektivitas Model Pbl(Problem Based Learning) Menggunakan Media Lagu Rumus Matematika Terhadap Hasil Belajar Siswa Kelas V \\ Sekolah Dasar}

pembelajaran, siswa mempresentasikan hasil diskusi yang mereka lakukan di depan kelas dan dievaluasi serta bersama-sama menarik kesimpulan.

Pada kelas kontrol yang menggunakan model pembelajaran biasa, guru lebih membimbing siswa dalam pembelajaran hanya melalui ceramah dan diskusi biasa saja, jadi siswa hanya bekerja sama dengan teman sekelompoknya dan kurang aktif dalam pembelajaran. Guru kurang dapat memahami siswa-siswa yang belum bisa menguasai materi palajaran dengan baik. Hal ini mengakibatkan kurangnya peningkatan kemampuan siswa dalam memecahkan suatu permasalahan dan penguasaan materi.

Dari semua aspek psikomotorik yang telah dilakukan, menunjukkan sebagian besar siswa dalam kelas eksperimen mempunyai respon yang bagus terhadap penerapan model pembelajaran Problem Based Learning menggunakan media lagu rumus matematika yang dilakukan dalam penelitian ini. Hal ini terlihat dalam kemampuan siswa menghafal rumus dengan menyanyika lagu rumus matematika dengan benar. Kemampuan siswa dalam menyanyika lagu rumus matematika dengan tepat disebabkan keingintahuan siswa mengenai kegunaan atau cara kerja dari dari media itu sendiri. Tingginya hasil belajar psikomotorik dengan model pembelajaran Problem Based Learning menggunakan media lagu rumus matematika disebabkan siswa secara langsung melihat, mendengarkan dan menirukan lagu rumus matematika. Berdasarkan uraian diatas dapat disimpulkan bahwa pembelajaran menggunakan model pembelajaran Problem Based Learning menggunakan media rumus lagu matematika pada pokok bahasan sangat membantu siswa dalam memperoleh hasil yang optimal sehingga pembelajaran lebih efektif. Dengan menggunakan media lagu rumus matematika, siswa menjadi lebih aktif dalam bertanya, saling kerjasama dalam berdiskusi, dan mempu dengan mudah menyelesaikan masalah yang berkaitan dengan volume bangun ruang. Dalam kondisi seperti ini siswa mampu memperlihatkan kemampuan individu dan kemampuan dalam berkelompok. Dalam pembelajaran ini yang berperan aktif adalah siswa bukan guru, guru sebagai motivator siswa dan mengarahkan kegiatan belajar mengajar saja.

Pembelajaran dengan media lagu rumus matematika mendorong keingintahuan siswa mengenai materi volume bangun ruang. Hal ini membuat 


\section{Wulan Sutriyani dan Herwin Widyatmoko : Efektivitas Model Pbl(Problem Based Learning) Menggunakan Media Lagu Rumus Matematika Terhadap Hasil Belajar Siswa Kelas V \\ Sekolah Dasar}

proses pembelajaran berlangsung secara alamiah dalam bentuk kegiatan siswa bekerja dan mengalami, bukan transfer pengetahuan dari guru ke siswa. Hal tersebut didukung dari hasil penelitian dari Supriadi (2013), bahwa terdapat perbedaan signifikan hasil belajar IPS antara kelompok siswa yang belajar menggunakan model pembelajaran problem based learning berbantuan media audiovisual dengan kelompok siswa yang belajar menggunakan pembelajaran konvensional kelas IV SD Gugus Ubud, Gianyar tahun ajaran 2012/2013.

Berdasarkan nilai NGain Score menunjukkan model PBL efektif untuk meningkatkan hasil belajar dalam mata pelajaran matematika materi volume bangun ruang pada siswa kelas $\mathrm{V}$, Sementara metode konvensional tidak efektif untuk meningkatkan hasil belajar. Selain itu, penelitian ini juga sejalan dengan hasil penelitian Prastica (2018) yang menjelaskan bahwa model pembelajaran Problem Based Learning berpengaruh terhadap hasil belajar siswa kelas V SD pada muatan pelajaran matematika.

\section{Simpulan}

Berdasarkan hasil penelitian dan pembahasan pada bab IV, analisis hipotesis dapat disimpulkan sebagai berikuit: (1) Pelaksanaan penggunaan media lagu rumus matematika menggunakan model PBL diberikan pada saat melakukan eksperimen. Penggunaan media lagu rumus matematika diterima sangat baik oleh peserta didik, hal ini terlihat dari antusias peserta didik memperhatikan penjelasan guru dan menyaksikan setiap video lagu rumus matematika yang ditayangkan pada saat penelitian dan intensitas bertanya meningkat mengenai apa yang tidak mereka ketahui serta merespon dengan cepat saat diberi pertanyaan; (2) Dengan menggunakan media pembelajaran lagu rumus matematika motivasi belajar peserta didik menjadi lebih meningkat dibandingkan dengan sebelum menggunakan media lagu rumus matematika. Rata-rata motivasi belajar saat sebelum menggunakan lagu rumus matematikaadalah 65,3 . Sedangkan rata-rata setelah menggunakan model PBL dengan media lagu rumus matematika menjadi 80,3 . Sehingga peningkatannya adalah 15; (3) Penggunaan media lagu rumus matematika menggunakan menggunakan model PBL efektif meningkatkan hasil pembelajaran dibanding model konvensional, setelah dilakukan uji independent 
Wulan Sutriyani dan Herwin Widyatmoko : Efektivitas Model Pbl(Problem Based Learning)

Menggunakan Media Lagu Rumus Matematika Terhadap Hasil Belajar Siswa Kelas V

Sekolah Dasar

sample $t$ test $\mathrm{T}$ hitung 3,469 $>$ T tabel 2,145 dapat disimpulkan bahwa Ho ditolak dan $\mathrm{Ha}$ diterima, yang berarti ada perbedaan rata-rata hasil belajar antara kelompok eksperimen dan kelompok kontrol. Ada perbedaan efektivitas yang signifikan (nyata) antara penggunaan model pembelajaran PBL dengan model konvensional untuk meningkatkan hasil belajar dalam mata pelajaran matematika materi volume bangun ruang pada Siswa Kelas V SD 1 Tegalsambi Tahun Pelajaran 2019/2020.

\section{DAFTAR PUSTAKA}

Afifah, Elva Pristy, dkk. 2019. Efektivitas Problem Based Learning dan Problem Solving Terhadap Kemampuan Berpikir Kritis Siswa Kelas $V$ dalam Pembelajaran Matematika. Journal of Mathematics Education, Science And Technology. Vol 4, No 1

Aizid, R. 2011.Sehat dan Cerdas dengan Terapi Musik.Yogyakarta: Laksana.

Alfian, dkk. 2019. Efektivitas Pembelajaran Model PBL Menggunakan AudioVisual untuk Meningkatkan Hasil Belajar Siswa Mapel IpaKelas VII.Unnes Physics Education Journal.http://journal.unnes.ac.id/sju/index.php/upej. ISSN 22526935.

Astari, Fajar Ayu, Suroso, dan Yustinus. 2018. Efektivitas Penggunaan Model Discovery learning dan Model Problem Based Learning terhadap Hasil Belajar IPA Siswa Kelas 3 SD. Jurnal basicedu prodi PGSD FIP UPTT 2018.Vol. 2 No.(1) 1-10.

Heller dan Heller. 2010. Pedagogi pemecahan masalah. http://sondangrina. blogspot.com/2013/03/pedagogi-pemecahan-masalah.html diakses 9 mei 2013

Masholekhatin, N.S. 2013. Pengaruh Model Pembelajaran Problem Based Learning (PBL) terhadap Hasil Belajar Geografi, Jurnal UM, hal 1-13 Diakses dari http://jurnal-online.um.ac.id/data/artikel/artikel842B30313E88 C7F60B08A3EE6FBD68FA.pdf

Muntoha, Mohammad dkk. 2012. Pengembangan Sistem Evaluasi Pembelajaran Berbasis WEB (WEB Base Learning Assessment System).Prosiding Pertemuan IImiah XXIV HFI Jateng \& DIY. hIm 195-199.

Prastica. 2018 . Pengaruh Penerapan Model Pembelajaran Problem Based Learning terhadap Hasil Belajar Siswa Kelas V Pada Muatan Pelajaran Matematika tentang Skala Di SDN Gambiranom. Https://repository.usd.ac. id/31760/2/141134030_full.pdf 
Wulan Sutriyani dan Herwin Widyatmoko : Efektivitas Model Pbl(Problem Based Learning) Menggunakan Media Lagu Rumus Matematika Terhadap Hasil Belajar Siswa Kelas V

Sekolah Dasar

Sugiyono. 2013. Metode Penelitian Kuantitatif Kualitatif dan $R \& D$. Bandung: Alfabeta.

Supriadi. 2013. Model Pembelajaran Problem Based Learning (PBL) Berbantuan Media Audiovisual berpengaruh terhadap Hasil Belajar IPS Siswa Kelas IV $S D$ Gugus Ubud gianyar. https://ejournal.undiksha.ac.id/index.php/JJ PGSD /article/view/1233.

Wulandari, Nestri Indah dkk. 2018. Efektivitas Model Pembelajaran Problem Based Learning terhadap Hasil Belajar Ipa Ditinjau dari Kemampuan Berkomunikasi Siswa. jurnalfkip.unram.ac.id/index.php/JPM/article/view/ 538.Vol.13 No.1. 